'N KONGRES OOR ARBEID EN INDUSTRIE 1984

'N VERANTWOORDING EN BEKENDSTELLING

C.W.H. Boshoff

In die pas afgelope Algemene Sinode van die Ned. Geref. Kerk (Oktober 1982) is $h$ aanbeveling van die ASSK goedgekeur dat daar in 1984 in samewerking met die ander lede van die Ned. Geref. Kerkfamilie h kerklike kongres oor Arbeid en Industrie gehou word. Eintlik is daaraan niks vreemds nie, want die Ned. Geref. Kerk is sedert die vroeër dekades van hierdie eeu al besig om aan die vraggstuk van verstedeliking, industrialisasie, verarming en die roeping van die Kerk in hierdie situasie aandag te skenk.

Kerklike Betrokkenheid

1.1 Die onderskeie sinodes het hulle van vroeg af geroepe gevoel om hulle te bemoei met die mens wat in die eeu van verandering in die ratte van ekonomiese en matskaplike kragte geval het en aan hulle h helpende hand uit te reik. So het die Kaapse Kerk reeda in 1915 h Armesorgkommisie in die lewe geroep. In 1945 hou die Transvaalse Kerk in Johannesburg h kursus vir matskaplike werksters oor die onderwerp: Die Codsdiens as Opheffingafaktor in Maatskaplike sorg. Hier verklaar ds J R Albertyn, Armesorgsekretaris in Transvaal: 'Die geweldige instroming van landelike armes na ons stedelike gebiede die laste 20 of 30 jaar het (egter) nuwe toestande en vraagstukke in die lewe geroep ....... .... die Kerk het hom met alle mag gewerp in die stryd om menswaardige lone vir die armes te verseker, gesonde arbeidstoestande, fatsoenlike behuising, kindersorg, ontspanning ens ..... Hoe kan trouens verwag word dat mense as christene sal lewe onder toestande van hopelose ellende, ontbering en krankheid"." )

Treffend word die Kerk se betrokkenheid in die vorm van Volkskongresse tot op daardie datum weergegee. Onder andere word die volgende gemeld:

1893 te Stellenbosch. Hoofonderwerp: "Ondoeltreffende onderys as hoofooraak van die Armblankevraagatuk";

1916 te Cradock: "Die landelike nood en die trek van die stede";

1922 te Stellenbosch: "Doeltreffende onderwys as redmiddel";

1923 te Bloemfontein: "Gesament like Kongres van Vier Gefedereerde Kerke"; 1934 te Kimberley, "Armblankevraagstuk in al sy aspekte". 2) 
Teen 1945 het die Ned. Geref. Kerk reeds meer as 100 maatskaplike werksters in diens gehad wat hulle in hoofsaak aan die stedelike situasie gewy het. In 1939 is die Rand se Armesorgraad gestig.

1.2 Na mate die probleme van die stad en die industrie toeneem, word daar ook wetenskaplik dieper aan die vraagstukke gewerk. In 1959 hou die Ned. Geref. Kerk sy eerste Uniale Evangelisasiekongres in die Stadsaal van Bloemfontein, 28-30 September 1959 ${ }^{3)}$ war kerkvervreemding met verstedeliking sterk in verband gebring word. Dit is egter tien jaar later in 1969 dat die geindustrialiseerde mens voluit in die fokus van die kerklike rekenskap gebring word. By hierdie kongres oor Rerk en Industrie word onder andere die volgende referate gelewer:

prof H D A du Toit: "Die bediening van die kerk aan die geindustrialiseerde mens"; dr J A Heyns: "n Prinsipiële ontleding van kerk en industrie in die lig van Gods Woord";

en prof J C G Kotzé: "Die kerklike antwoord op die industriële eise van ons dag". 4)

Monografieë en proefskrifte oor dieselfde aangeleentheid bly ook nie uit nie en aangevul met studies uit die buiteland, word die tema kerk en industrie in die volgende twee dekades veelvuldig gehoor.

Uit die ouer garde is dit nogeens die moeite werd om na $J$ R Albertyn se Kerk en Stad, ${ }^{5)}$ te verwys en effens later uit Nederland, in boek met dieselfde titel van P Smits. ${ }^{6)}$

Ons mak in Suid-Afrika ook kennis met die navorsing van sosioloë soos C J Alant wat in 1969 die moderne lidmaat van die Ned. Geref. Kerk aan die predikant voorstel. ${ }^{7)}$

Dan is daar die MA-verhandeling van $\mathrm{P} J$ Jordaan, $h$ predikant van die Ned. Geref. Kerk wat in 1967 skryf oor enkele aspekte van die gesin in die industriële wêreld. ${ }^{8)}$

In 1971 verskyn th verwerking van h doktorale proefskrif van dieselfde outeur onder die titel: Die sosiale probleme en taak van die Kerk in die industriële gebied. ${ }^{9)}$ 
Dit is $h$ besliste aanvulling by die doktersgraad van $E \mathrm{~J}$ Marais wat in 1969 promoveer met die proefskrif: Pastorale sorg aan die mens in die bedryf. n Pastoraal psigologiese studie van die bediening van die kerk aan die mens in die bedryf van die twintigste eeu. ${ }^{10)}$ Dit sluit ook aan by die publikasie van E de Vries: De dienst van de kerk aan de industrie arbeider. ${ }^{11)}$

h Ander skrywer wat die kerk ook ernstig van die mens in die industrie bewus gemaak het, was H Symanowski. ${ }^{12)}$

1.3 Daar kan dus met reg gesê word dat die Ned. Geref. Kerk getrag het om die aktualiteit van die industrievraagstuk met groot erns te benader. En tog het ons met die Kongres wat vir 1984 in vooruitsig gestel word, h nuwe dimensie wat in vorige kongresse nie aanwesig was nie. Dit lê veral in die instansies aan wie die kongres opgedra word, wat daaraan deelneem en wie dit voorberei. Nie alleen is dit van belang dat die voorstel vir die hou van die Kongres van die Algemene Sinode se Sendingkommissie gekom het nie, maar ook dat al die groot permanente komnissies van die arbeid van die Kerk, $\mathrm{nl}$. Die Algemene Kommissie vir die Diens van Barmhartigheid, die Algemene Kommissie vir Ampsbediening en Evangelisasie en die Algemene Jeugkomissie met verteenwoordigsters van die Vrouediensaksie angesê is ow die Kongres in samewerking met die Ned. Geref. Sendingkerk, die Ned. Geref. Kerk in Afrika en die Reformed Church in Africa voor te berei. Al hierdie instansies het reeds hul wil om saam te werk betuig en hulle verteenwoordigers op die reëlingskomisisie en die panele aangewys. Daar word reeds druk gewerk aan die voorbereiding van die Kongres op interkerklike vlak.

Die kongres in beplanning

Die uit leg van die kongres lyk soos volg:

2.1 Die tema: Arbeid en Industrie: die roeping en verantwoordelikheid van die Kerk, vandag en môre,

2.2 Tyd en plek: Die Kongres word DV gehou op 4-6 Julie 1984 by die Universiteit van Pretoria.

2.3 Die teikengroep: As teikengehoor van die kongres word die kerk as geheel bedoel, maar as teikengroep word \pm 1000 afgevaardigdes uit die Ned. Geref. Kerkfamilie in vooruitsig gestel. Afgevaardigdes sal op h pro-rata wyse benoem word. 
2.4 Die doel: Die doel van die Kongres is om kerklike afgevaardigdes saam te trek on die kerk ten onsigte van kennis, houdings en vaardighede bewus te maak en in staat te stel om vandag en môre sy roeping en verantwoordelikheid ten opsigte van die mens in arbeid en industrie te kan nakom.

2.5 Die voorbereiding: h Reëlingskomitee saamgestel uit verteenwoordigers van die ASSK, AKDB, AKAE, AJK en die Vroueaksie, van die Ned. Geref. Kerk, en verteenwoordigers van die Ned. Geref. Sendingkerk, die Ned. Geref. Kerk in Afrika en die Reformed Church in Africa met drie werkspanele van deskundiges, is verantwoordelik vir die voorbereiding van die Kongres.

\subsection{Werksopdragte aan paneel 1 wat bestaan uit:}

Di E M Mataboge

J Mettler

$\mathrm{J}$ A Hough

J G Griesel

D J Viljoen

mev Burgers

dr $\mathrm{P}$ van der Merwe

proff $J$ A van Wyk en C H Boshoff

en $C W H$ Boshoff (paneelleier)

word opgedra: "Die kerk kyk na die moderne industriële wêreld:

- Die aard en funksionering van die industrie en die tegniek

- Die sosiale en politieke magte op die terrein van industrie en tegniek".

Paneel 2 wat bestaan uit:

Di C Colyn

W J C Cilliers

J G Botha

E C D Bruwer

mev G Malan

Imr $D$ W de Beer

drr H M Beets, M T S Zeeman, J I de Villiers, S J Eloff

proff A J Smuts, I J van Eeden en J H Smit (paneelleier)

en aan hulle is opgedra: "Die Kerk kyk na die industriële mens en gemeenskap:

- Die posisie van die indiwiduele rens en die industrie

- Die posisie van die gemeenskap in die industrie". 
Paneel 3 bestaan uit:

Di E M Lebone

P C Poley

M Smuts

D S Snyman

drr M M Niewoudt, H J Möller, L C Dressel

mev Wolmarans

proff A C Barnard, D Crafford (paneelleier)

en hulle taakopdrag lui: "Die Kerk kyk na homself en sy diens aan die industriële wêreld.

- Wie is die Kerk?

- Die lewe van die Kerk

- Die taak van die Kerk - diens, getuienis, aanbidding, verkondiging

- Die struktuur van die Kerk

- Die arbeid wat lei

- tot vrug

- tot eer van God".

2.7 Werksmetode: Elke paneel moet in die aanpak van sy opdrag aan die volgende drie aspekte aandag gee:

2.7.1 Kennis:- waaronder die duidelike definiëring en ontleding van die opdrag plassind. Hier word die klem op die kennisvlak van die situasie, die problematiek en die optrede wat dit verg, gelê.

2.7.2 Houdings:- waaronder evaluering, voorkeure, besware, afkeure en motivering aandag geniet. Dit moet besluitneming voorberei en $h$ dinamiese gesindheid opwek.

2.7.3 Vaardighede:- waaronder die bevordering van die keuse en voorkeure, in die Kongres self, mar ook deur beplande optrede van die Kerk as geheel, of deur opdragte van $h$ voortsettingskomitee, $h$ buro, personeel - of hoe die paneel dit ookal voorstel, kan geskied en hoe negatiewe faktore bestry of uitgeskakel kan word.

By die kerk word die klem dikwels op die kennis en die houding gelê, maar beklemtoning van vaardighede, oor die hoe van die optrede word daar nie soveel voorligting gegee nie. Daarom moet die instelling van $h$ buro oorweeg word wat permanente voorligting kan vergkaf oor die uit- 
voering van die aspekte wat aanbeveel word.

Panele word ook versoek om in hulle voorbereiding aandag te gee aan die profetiese, priesterlike en koninklike dimensies van die christen en die kerk se lewe.

\subsubsection{Die Dagbestuur van die beplanningskomitee bestaan uit prof $C$ W H Boshoff (voorsitter) dr M M Nieuwoudt en dr A M Hofmeyr (sekretaris).}

2.8 Voortgang. Op 14 Februarie het die beplanningskomitee en al die verteenwoordigers van die kerke en kommissies vir n werksessie in die geboue van die SA Bybelvereniging vergader en met groot geesdrif is die uitdaging aanvaar.

Daar word gehoop dat hierdie Konges wat ruimte bied vir die verskillende kerke in die N G Kerkfamilie om saam te besin en te beplan, die geleentheid sal aangryp om h verreikende invloed op kerklike verhoudinge uit te oefen. Dit sluit aan by die verslag oor die nuwe sendingsituasie waaroor die ASSK in 1978 by die Algemene Sinode berig het, waar onder andere die volgende gesê word: "Gesien die oorweldigende tendens ten opsigte van verstedeliking met gepaardgaande nywerheidspatrone wat die lewensitme van mense totaal verander, het dit nodig geword om op $n$ gesentraliseerde wyse hieraan aandag te gee. Dit kan nooit plaasvervangend vir plaaslike gemeentes wees nie, maar h stedelike sendingaksie rondom $h$ sendingsentrum moet gesamentlik deur kerke vir groot stedelike komplekse oorweeg word". "13)

3 Industrialisasie en verstedeliking van die Bantoe

Hoe belangrik dit is dat die Ned Geref Kerk in Afrika by hierdie voorbereiding en deelname aan die kongres betrek word, blyk uit $n$ indringende studie wat hierdie kerk reeds in 1971 oor bogemelde onderwerp gemaak het. Dit loon die moeite om na enkele uitsprake uit die verslag te luister. Daar word verklaar: "Vir die Bantoe wat reeds vir twee geslagte (en in somige gevalle drie geslagte) in die stad woon, het die geindustrialiseerde bestaan nou $h$ lewenswyse geword". Oor implikasies van industrialisasie en verstedeliking word verklaar: In die stad word eie arbeids-en ekonomiese solidariteit van grootfamilie ontwrig en dan vervang deur arbeids-en ekonomiese wedywering. Die bedryfslewe van die stad dra met ander woorde nie h gemeenskapskarakter nie. 
Individuele mense word gekoördineer in $h$ bepaalde organisasievorm onder leiding van $h$ winsmotief met skerp konkurrensie as onvermydelike gevolg. Sy trek na die stad het daarom vir die Bantoe beteken dat hy nie alleen in h vreemdsoortige werk kom staan het nie, maar dat hy ook h nuwe denk- en gedragspatroon insake sy werk moes opbou". Wanneer daar oor die industriearbeider en sy werk gehandel word, blyk die problematiek uit aspekte soos werkskeuse, werksinduksie, arbeidsbetrokkenheid en loonoorweginge, arbeidsekuriteit, gemeenskapsbehoefte in arbeid, verhouding tot werkers en arbeidsritme.

Oor godsdienstige implikasies word onder andere verklaar: "Namate die industrialisasie vorder, verminder die noodsaaklike religieuse behoeftes ten opsigte van arbeid. Die loon op die arbeid kom reëlmatig en is nie afhanklik van natuurlike of bonatuurlike magte nie. Die behoefte aan sekuriteit word eventueel nie deur religieuse nie, maar deur die materiële bevredig".

Oor die roeping van die Kerk word gesê: "Eers wanneer die kerk self bewus geword het van die nood van die bantoe in die verstedelikte en geindustrialiseerde samelewing, sal hy hom kan wend na owerheid, bedryf ens. wet die appél dat elkeen op sy terrein daarna sal strewe om $h$ verantwoordelike weg te vind, in ooreensteming met die christelike norme, on h einde te maak aan die toestand van sekuriteitloosheid en ontwrigting ${ }^{14)}$.

Sedert 1971 het daar weliswar baie dinge ten opsigte van die swart arbeider se lone, werksomstandighede en wette en regulasies verander maar dit is baie duidelik dat verteenwoordigers uit hierdie Kerk $n$ belangrike bydrae op die Kongres kan lewer.

Die N G Sendingkerk besin oor arbeid en industrie

Die Ned Geref Sendingkerk in Suid-Afrika is $n$ kerk met gevestigde werksamhede ten opsigre van diens van baxmhartigheid en die probleme rondom die verstedeliking van die Kleurlingbevolking. Toe die versoek van die ASSK van die Ned Geref Kerk ontvang is om "n deeglike studie te mak van die posisie van die Kleurlinge in die industrie". "15) het die saak dadelik aandag gekry. Die Sinode van 1974 het die volgende beskrywingspunt aanvaar. 
"Die sinode dra dit aan die Kormissie vir Sending en Evangelisasie op, om h studie te maak van die kerklike situasie in die industrie met spesiale toespitsing op die geestelike behoeftes van die Kleurlingwerkgewers en werknemers en om die resultate van hierdie ondersoek so spoedig moontlik aan die skakelkommissie (tussen die NGK en NGSK, Boshoff) beskikbaar te stel vir deursending aan die SSK en ASSK. Verder word dit aan die Kommissie opgedra om in die behartiging van die evangelisasie-aksie in die lig van die bevindinge van die ondersoek te handel". 15a)

Die deur was dus onmiddellik oop vir samewerking van die kant van die Ned Geref Sendingkerk toe die uitnodiging in verband met die hou van die Kongres oor Arbeid en Industrie ontvang is.

Knelpunte in die totale opset van volke, arbeid, verstedeliking en industrialisasie

Dat ons in die RSA met $n$ ingewikkelde situasie te doen het, blyk ook reeds uit die opdragte wat an die panele gegee is. Van die belangrikste is waarskynlik die feit dat ons nie met arbeid en industrie in homogene gemeenskap te doen het nie. Inteendeel juis die heterogeniteit van volke en volksgroepe, van kulture en ontwikkelingsfases warin mense hulle bevind - die feit dat ons eerste en derdewêreld-gemeenskappe het, maak die probleme has onoplosbaar. Maar juis daarom het die Kerk as draer van die versoeningsboodskap $h$ taak wat hy nie kan vermy nie. Hierdie taak moet egter nie naief of oppervlakkig benader word nie. Juis in die erns warmee met die kernfeite van die situasie rekening gehou word, sal die bydrae van die Kerk gemeet word. Dan moet veral op die volgende gelet word:

\subsection{Die bevolking van Suid-Afrika - ooreenkomste en verskille.}

Die eerste kernfeit ten opsigte van die mense van die subkontinent is die basiese eendersheid van algemeen menslike behoeftes soos aan sekuriteit, verwesenliking, die vervulling van ideale en aspirasies wat by almal aanwesig is. Daarteenoor kan die diepgaande verskille wat tussen hulle bestaan nie genegeer word nie. Die groot fout wat ten opsigte van die mense van Suid-Afrika gemaak word, is dat hulle net getel word, asof hul getalle die belangrikste feit is warmee rekening gehou moet word. Word daar nog van verskeidenheid gepraat, word gehandel asof hulle kleur die deurslaggewende faktor is - dat daar Blankes en Nie-Blankes, of Blankes, 
Gekleurdes, Asiërs en Swart mense is. Dan is ons hastig om van Swart woongebiede, Swart arbeid, Swart skole, Swart verstedeliking, Swart industrialisasie, Swart meerderheid, ens. te praat. Die miskenning van die feit van die volkereverskeidenheid is die resultaat van die kolonialisme en ons onvermoë om onsself daarvan los te maak. In werklikheid, sê dr W J Breytenbach en mnr Wilf Nussey, verwysende na die verskeidenheid in Afrika: "Their variety is far wider than in Europe, not only in culture, but also genetically - supporting the growing scientific belief in 'multi-genesis', that mankind envolved from not one or a few but many homimid creatures in many places". Oor ons buurstate verklaar hulle: "It is being seen again now in the Rhodesian conflict, which is increasingly a Shona versus Ndebele tribal war en less and less a black-white one". Van Angola sê hulle: "In Angola too, die civil war is primarily between ethnic groups ..." (The Ethnic Reality, The Star, August 18, 1978).

Prof Christof Hanekom bevind in h studie oor Kontra-Akkulturatiewe houdinge en verskynsels in Afrika, die herontdekking van die Afrikakultuur na eeuelange kolonisasie en praat selfs van die kulturele rehabilitasie van die Swart man. (n Verkenning van enkele Kontra Akkulturatiewe houdinge en verskynsels in Afrika, Dept Volkekunde, Stellenbosch, p. 2.3).

Elkeen wat maar net wil ag gee op die feit sal die verskil tussen Zoeloe en Xhosa of tussen Noord-Sotho en Shangaan ens, waarneem. Nasiebou is h proses van die post-koloniale era, ook in Suid-Afrika. Vir baie mense bestaan die verskille tussen die Swart volke uit blote stamverskille (tribal differences). In werklikheid is die verskillende etniese groepe uit groot getalle stamme opgebou.

Sien Tabel 1 . 
Tabel 1. Die Swart volke van Suid-Afrika (onafhanklike state ingesluit) met die aantal stamme waaruit hulle saamgestel is 1979 (000)

Onafhanklike state

$\begin{array}{llcr}\text { Staat } & \text { Taal } & \text { Stame } & \text { Getal } \\ \text { Transkei } & \text { Xhosa } & 138 & 4253 \\ \text { Bophuthatswana } & \text { Tswana } & 72 & 2279 \\ \text { Venda } & \text { Venda } & 27 & 486 \\ \text { Ciskei } & \text { Xhosa } & 40 & 1051\end{array}$

Subtotaal

8069

Selfregerende state

Gazanku lu

Tshonga

Suid Ndebele

Swazi

Zoeloe

N Sotho

S Sotho
41

9

14

203

123

2
882

306

639

5449

2416

I 840

Subtotaal

11532

Totaal

19601

On hierdie werklikheid van volkereverskeidenheid onder die Swart mense van Suid-Afrika uit die oog te verloor en nie te besef watter implikasies dit op die verhoudinge en die sosio-politieke ontplooiing binne die subkontinent sal hê nie, is ơ enige verdere gesprek sinloos te maak.

\subsection{Die Bevolking van Suid-Afrika - mense wat vermenigvuldig.}

in Tweede kernfeit is die vermeniguldiging van mense, terwyl daar nog steeds van sekeres te min is. Die kortste weg om dit uit te druk, is in die projeksie van bevolkingsgroei tot die jaar 2000 na Christus. In die lig van bogenoemde volkereverskeidenheid word die verskillende Swart volke ter wille van vereenvoudiging van die statistieke saamgevoeg. 
Cabe 1 2. Bevolkingsaanwas in Suid-Afrika beraam tot 2000 na Christus (000)

$\begin{array}{lcccccc}\text { Jaar } & \text { Swart volke } & \text { Indiërs } & \text { Kleurlinge } & \text { Blankes } & \text { Totaal } \\ 1970 & 15400 & 640 & 2080 & 3800 & 21920 \\ 1980 & 20280 & 800 & 2550 & 4370 & 28000 \\ 1985 & 23300 & 890 & 2800 & 4700 & 31690 \\ 1990 & 26770 & 980 & 3100 & 5000 & 35850 \\ 1995 & 30550 & 1050 & 3400 & 5300 & 40300 \\ 1000 & 34750 & 1130 & 3700 & 5600 & 45180\end{array}$

Opmerking: Die gevolg van hierdie demografiese tendense dui nie slegs op $h$ redusering van die Blanke in Afrika nie, maar bring ook mee dat die Blanke wat vir meer as 90 persent van alle werkgeleenthede in Suid-Afrika verantwoordelik is, besig is om na die end van die eeu tot minder as 13 persent van die totale bevolking te daal.

5.3 Die Bevolking van Suid-Afrika - mense in stede en industrieë.

Die derde kernfeit ten opsigte van die mense van Suid-Afrika is die onkeerbare proses van verstedeliking in industrialisasie wat moet plaasvind en wat saamval met vraagstukke soos behuising, werkverskaffing en onderwys en opleiding.

Die bevolkingsgroei van die volkere van Suid-Afrika kan grootliks net in stede en industrieë geakkommodeer word.

Stedelike mense moet al meer in die "moderne sektor" van die arbeid opgeneem word.

Die moderne sektor van die bedryf is van geskoolde arbeid, intrepreneurskap, kundigheid, kapitaal en stabiliteit afhanklik.

Sien Tabel 3. 
Tabel 3. Suid-Afrika se stedelike en plattelandse bevolkingsgroepe 1980-2000

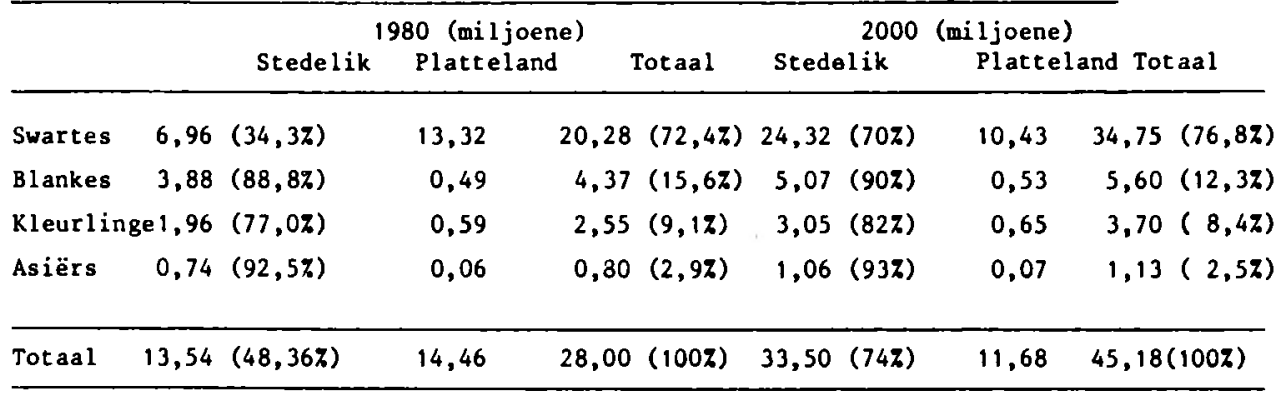

Hieruit blyk dat die Blankes, die Kleurlinge en die Asiërs se verstedelikingsproses grotendeels afgehandel is, terwyl die Swart volke wat in 1980 slegs 34,3 persent verstedelik was, teen 2000 tot 70 persent en selfs tot 75 persent kan toeneem. Dit beteken 17,36 miljoen Swart mense wat moet verstedelik.

Ten opsigte van behuising sal dit h ontploffing in die tempo van oprigting van Swart behuising meebring - van sowat 15000 - 20000 eenhede per jaar in die 1970s tot meer as 120000 eenhede per jaar in die 80 s en tussen $150000-200000$ eenhede per jaar in die 1990s.

Naas behuising is werkverskaffing een van die grootste knelpunte in die groei en verstedeliking van die bevolking.

Tabel 4 gee $h$ aanduiding van die implikasies ten opsigte van die ekonomiese bedrywigheid en die behoefte aan werkverskaffing tussen 1980 en 2000 in Suid-Afrika.

Tabel 4. Ekonomiese bedrywige persone (miljoene)

\begin{tabular}{|c|c|c|c|c|}
\hline & 1980 & 2000 & & Toename \\
\hline $\begin{array}{l}\text { Totale bevolking } \\
\text { Nie-ekonomies-bedrywig } \\
\text { Ekonomies-bedrywig } \\
\text {-in periferale sektor } \\
\text {-in moderne sektor }\end{array}$ & $\begin{array}{l}28,00 \\
17,4 \quad(627) \\
10,6(387) \\
4,3 \\
6,3\end{array}$ & $\begin{array}{r}45,18 \\
26,93 \\
18,25 \\
5,94 \\
12,31\end{array}$ & $\begin{array}{l}(59,6 z) \\
(40,47)\end{array}$ & $\begin{array}{r}17,18 \\
9,55 \\
7,65 \\
1,64 \\
6,01\end{array}$ \\
\hline
\end{tabular}

op die volgende feite moet die andag gevestig word:

(i) Die nie-ekonomies-bedrywige bevolking van $17 !$ miljoen (627) word 27 miljoen (60\%) in 2000. 
(ii) Van die ekonomies-bedrywige bevolking van 10,6 miljoen (387) in 1980 was slegs $6,3 \mathrm{miljoen}$ (slegs $221 \%$ van die totale bevolking) in die moderne sektor werksaam, terwyl die res in periferale bedrywe, naamlik in selfversorgings-ekonomieë van die nasionale state en as huisbediendes werksaam was.

(iii) Die ekonomies-bedrywiges in die moderne sektor sal tot 12,3 miljoen styg in 2000 , dit is $27 \frac{1}{2}$ van die totale bevolking en dit is bykans $n$ verdubbeling op 1980. Gevolglik sal die moderne sektor van die Suid-Afrikaanse ekonomie 6 miljoen bykomstige werkgeleenthede moet skep, dit wil sê gemiddeld 1000 per werkdag. Hierna sal daar in die jaar 2000 nog byna 6 miljoen $(5,94 \mathrm{~m})$ ekonomies-bedrywiges uit die periferale sektor $h$ bestaan moet maak.

Tabel 5 gee $h$ aanduiding van die werkgewerspotensiaal van die moderne sektor. Welke enorme eise dit op die skoling van mense gaan lê, blyk duidelik:

Tabe 1 5. Werkgewerspotensiaal: Moderne sektor

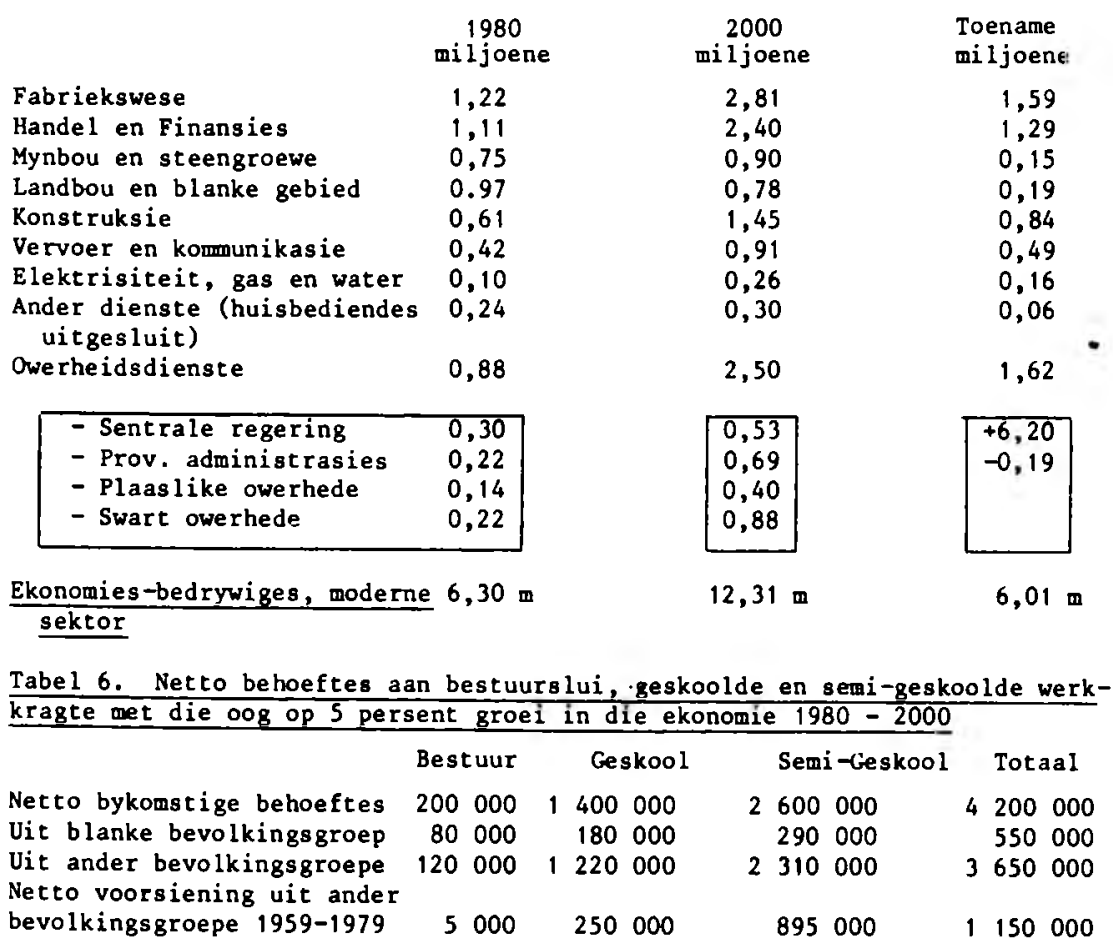




\section{Opmerking :}

Die knelpunt vir ekonomiese groei lê dus bes 1 is by die hooggeskoolde en bestuursbehoeftes. Die syfers dui onbetwisbar daarop dat opleiding vir die 1 and se geskoolde behoeftes buitengewoon en baie gou verhoog moet word, anders sal die groei van die ekonomie ernstig geknou word en werkloosheid en inflasie afmetings anneem wat die land se stabiliteit kan bedreig. Werksgeleenthede word deur bestuurslui en geskoolde mense geskep.

\subsection{Die Bevolking van Suid-Afrika - sosio-politieke eise}

Die vierde kernfeit ten opsigte van die mense van Suid-Afrika is dat hulle ook sosio-politieke eise stel.

Die feite hierbo gestel, is oorweldigend maar daarom nie minder werklik nie. Stelselmatig het dit geblyk dat die konsekwensies daarvan nie ontkom kan word nie. Dieselfde geld van die vierde kernfeit. Mense stel ook sosio-politieke eise. Dit is betekenisvol dat van die nuwe geskoolde arbeid wat vereis word, byna 90 persent van die nie-blanke bevolkingsgroepe moet kom. Geskoolde mense het gesag, seggenskap en mag. Tot dusver was die Nie-Blanke, veral die Swartes, prakties geen faktor in die gesaghebbende arbeidskomponent nie. Geprojekteer op die jaar 2000 sal ons egter met h Swart bevolkingskomponent te doen hê wat ingrypend verskil met die van vandag :

(i) Van die totale getal permanente stedelinge sal $72 \downarrow$ persent Swart wees .

(ii) I Geweldige verhoging van onderwyspeil van die Swart man sal plaasgevind het.

(iii) Sowat 80 persent van die addisionele geskoolde poste, 80 persent van die semi-geskoolde poste en as dit kan, sal 40 persent van die addisioneel-benodigde bestuursposte deur Swartes beklee word.

(iv) Die Swart man wat nie reeds deur sy verhoogde gesag in die arbeidsituasie en sy verhoogde onderwys-en opleidingspeil bewus sal wees van sy veranderde funksionele en sosiale status nie, sal deur binne- en buitelandse beinvloeding daarvan bewus gemaak word. 
(v) As hierdie veranderde lewenswyse, denkwyse, aspirasies en belange wat met die beroeps- en ekonomiese verantwoordelikhede en gesag gepaard gaan, nie politieke eise meebring nie, sal die mens nie meer mens wees nie.

(vi) As die bestaande migrasie en vestigingstendense voortgaan om hulself te verwerklik, sal ons voor die volgende onomstootlike situasie te staan kom:

- 241 miljoen verstedelikte Swart mense wat die oorwegende arbeidsmag van Suid-Afrika uitmaak - dan geskool, semigeskool en ongeskool sal permanent gevestig wees.

- Die 18,25 miljoen ekonomies-bedrywiges in Suid-Afrika sal soos volg versprei wees:

In die vier metropolitaanse gebiede $7,86 \mathrm{~m}$ In die res van die "blanke" land 5,71 un Binne Swart nasionale state $4,68 \mathrm{~m}$

Totaal 18,25 m

Dit wil sê 13,57 miljoen in die "blanke land" en 4,68 in die "Swart state".

- Meeste dorpe en stede in die nasionale state sal op die grense gevestig wees terwyl dorpe dieper in die tuisland hoofsaklik bejaardes, weduwees en pendelaars met hulle gesinne sal huisves.

- Etniese heterogeniteit sal die voortdurende druk van Swart solidariteit en Swart polarisasie ondervind, veral as die propaganda. daarin slaag om die Blankes as gemeenskaplike vyand en onderdrukker voor te hou.

- Geintegreerde werkstrukture, belange, verantwoordelikhede van permanente en gevestigde aard, is vir die verstedelikte Swart mense soos vir die Blanke, die Asiër, en die Kleurling veel meer as net $h$ geografiese fisiese konsentrasie. Die sosio-ekonomiese en politieke gevolge sal nie ontbreek nie. Vanselfsprekend sal hulle beroepe, hul werk, hul omgewing, leefwyse, probleme, denkwyse, belange en aspirasies vir hulle $\mathrm{n}$ nuwe lewe ontvou. In hulle miljoene is hulle in direkte aanraking wet die westerse stedelike atmosfeer, met die behoeftes van die stedeling. Etniese heterogeniteit ten spyt, sal hulle dieselfde omstandighede, probleme en griewe ervaar en dieselfde ekonomiese en politieke eise en aspirasies hê. Hierdie gemeenskaplikheid van verwagtings, verhoogde 
onderwys - en opleidingspeil en in die arbeidsgesagstruktuur, gepaard met permanentheid, sal etnisiteit op die agtergrond dwing. Dit is alleen maar realisties dat hulle hulself as in stedelike magsgroep sal sien, met eise en belange waar hulle woon, werk en permanensie het - war hulle totale belange is en ten opsigte warvan hulle op sosio-ekonomiese en politieke regte en toegewings sal aandring met die mag van getalle, die gesag in die arbeidstruktuur en hulle koopkrag on hulle te rugsteun.

Die $13 !$ miljoen van die totale bevolking van Suid-Afrika wat in 1980 verstedelik was, sal, waarskynlik met 20 miljoen toeneem tot 33 ! miljoen. Van hulle sal dan $24 \frac{1}{2}$ miljoen Swartes, 3 miljoen Kleurlinge en Asiërs en 5 miljoen Blankes wees. Vir elke 100 stedelinge sal daar in 2000 73 Swartes, 15 Blankes, 9 Kleurlinge en 3 Asiërs wees. Hierdie Swartes in die stede sal onafwendbaar $h$ politieke faktor word, wie se aansprake nie negeer sal kan word nie.

- Die kernfeite rondom die bevolkingstendense dwing ons tot die gevolgtrekking dat die $B$ lankes in $\mathrm{h}$ realistiese tydperk van $20 \mathrm{jaar}$ vorentoe in so $n$ minderheidsposisie geplaas sal word dat die Swartes, veral onder $h$ sterk leier, so $h$ solidariteit sal opbou dat die Kleurlinge en Asiërs nie meer anders sal kan as om met hulle teen $h$ blanke minderheidsregering te verenig nie.

- Die ervaring van Afrika is egter dat Swart solidariteit net hou solank as wat daar h sterk gemeenskaplike vyand geidentifiseer kan word. Sodra die 'vyand' geëlimineer is, breek dit op en tree etnisiteit en etniese leiers na vore vir die volgende fase van die stryd wat die vorige eeu in verskrikking, geweld en selfs volksmoorde ver oortref. Die Biafrane in Nigerië is slegs maar een van die sprekendste voorbeelde. Die solidariteit van 'stedelike Swartes' word dan verruil vir etniese solidariteit wat tussen stedelik gemeenskappe en die uit die nasionale state gesmee word.

Samevattend is die redelike gevolgtrekking wat die kemfeite en die projeksie van tendense daaromheen ons bied, dat daar has geen hoop vir vrede in $h$ proses van integrasie van die twaalf volke en volksgroepe 
tot $\mathrm{h}$ eenheidstaat en een politieke struktuur in Suid-Afrika gekoester kan word nie. In die oorweging van die sosiale en politieke magte op die terrein van die industrie en tegniek sal hiermee rekening jehou moet word. ${ }^{16)}$

Slot

Die onderneming om hierdie kongres oor arbeid en industrie in 1984 te hou en die Kerk die geleentheid te gee om te besin oor sy roeping en verantwoordelikheid vandag en môre, is $n$ geloofsdaad. Om daarvan $h$ sukses te mak sal egter ook inspanning noodsaaklik wees - nie alleen van hulle wat die kongres voorberei nie, maar ook van die deelnemers. Dit sal goed wees as afgevaardigdes na die kongres reeds teen Februarie 1984 aangewys kan word, om hulle ook in staat te stel om hulle deeglik vir hul deelname voor te berei.

Dit sal ook nodig wees dat die Kongres self ernstig besin oor die wyse waarop sy besluite uitgevoer en gemonitor word. Die nasorg van die kongres is selfs belangriker as die voorbereiding. Mag dit aan die Ned. Geref. Kerkfamilie gegee word om $h$ wesenlike bydrae in die veld van arbeid en industrie te lewer.

NOTAS

1. J.R. Albertyn, Die siel van opheffing, toesprake oor die onderwerp: Die Godsdiens as opheffingsfaktor in matskaplike sorg, gelewer op die kerklike kursus vir sosiale werksters gehou van 3 - 5 April 1945 in die Waterval-Volkshuis, Johannesburg, 21, 22, 23.

2. A.w., 30 .

3. Die Ned. Geref. Kerk en sy Evangelisasietaak vandag, NGKU, Pretoria en Kaapstad, sj.

4. Vgl. gedrukte referate Kerk en Industrie, April 1969.

5. Stellenbosch, Pro Ecclesia 1947.

6. Kerk en Stad, S'Gravenhage 1952.

7. C.J. Alant, h Sosiologiese studie van die beeld wat die gemeentelid in die Ned. Geref. Kerk van die predikant het, N.G.K.B. 1969.

8. Ongepubliseerde MA-verhandeling, PU vir CHO.

9. Tabelberg, Kaapstad 1971. 
10. Ongepubliseerde doktorsproefskrif, Stellenbosch 1969.

11. Franeker, T. Wever 1962.

12. Vgl. ook The christian witness in an industrial society, London 1966.

13. Vgl. Die nuwe sendingsituasie, bylae tot die verslag van die Algemene Komissie vir Sending, Oktober 1978, 26.

14. Industrialisasie en Verstedeliking van die Bantoe. Verslag aan die Algemene Sinode van NGKA te Tshilidzini, Agenda 1971, 121-127.

15. Vgl. Handelinge van die een-en-twintigste vergadering van die $H E$ Sinode van die Ned. Geref. Sendingkerk in SA 1974, 237.

15a. Handelinge $1974,286$.

16. Tabelle, statistieke en projeksies hierin gebruik, is verwerk uit gegewens van navorsers soos dr P Smit van die RGN, prof J L Sadie van Stellenbosch en prof $J$ A Lombard van UP.

\section{Addisionele literatuur}

1. Banning, W., Moderne maatschappijproblemen, Haarlem 1960.

2. Beyerhaus, Peter, Missions which way? Humanization or redemption, Zondervan, Grand Rapids 1971.

3. Blauw, J., De weg der zending, Kok, Kampen 1960.

4. Cox, Harvey, The secular city, London 1965.

5. Crafford, D., Die sosiale betrokkenheid van die kerk in die ekumene, sending en praktyk, NGKB, Pretoria 1978.

6. Durand, J.J.F., Swartman, stad en toekors. Tafelberg, Kaapstad 1970.

7. Jager, 0. e.a., Het koninkryk cods in de fabriek, 2 de dr. Franeker, T. Wever $s \cdot j$.

8. Nümberger, K. ed., Affluence, poverty and the word of God, A missiological institute publication, The Lutheran Publishing House, Durban 1978.

9. Wilmore, Gayrand S, The secular relevance of the church, Philadelphia 1962.

10. The Church for the others. Two Reports on Missionary structure of the congregation, W.C.C., Geneva 1968. 